\title{
DECREASE IN FREE FATTY ACID CONTENT AND COLOR AT USED COOKING OIL WITH ACTIVATED CARBON OF REEDS (Imperata cylindrica L. Raeusch)
}

\author{
Samsuar, Laila Susanti, Umia Ulfa \\ Department of Pharmacy Faculty, University of Tulang Bawang Lampung \\ Email : $\underline{\text { mrsam utb@yahoo.co.id }}$ \\ 082379693276
}

\begin{abstract}
Cooking oil is one of the foods that are needed by the community in daily life. The use of cooking oil continuously at high temperatures, produces cooking oil that is no longer feasible to use. Therefore, it's necessary to purify used cooking oil so that it can be reused for nonfoood purposes such as making soap or biodiesel fuel. This purification process is utilie the activated carbon of reeds (Imperata cylindrica L. Raeusch) as an adsorbent to reduce the levels of free fatty acids and colors in used cooking oil. Free fatty acid content test using acid base titration method and color change using Uv-Vis spectrofotometry method. This study aims to determine the optimum concentration of reeds activated carbon as an adsorbent in reducing the levels of free fatty acids and colors in used cooking oil, which consists of the concentration of reeds activated carbon which is a consentration of 2,5; 5; 7,5; 10; dan 12,5\%. The results of variance analysis showed the optimum concentration of reeds activated carbon to reduce the levels of free fatty acids and colors absorbance in used cooking oil at a concentration of 7,5\%. The percentage of decreasing levels of free fatty acids gorengan and pecel lele are $78.57 \%$ and $78.85 \%$. Decrease in absorbance of gorengan color from 1,792\% to $0,384 \%$ and the pecel lele color absorbance from 2,521 to 0,515.
\end{abstract}

Keywords : Activated Carbon, Color, Free Fatty Acid, Reeds, and Used Cooking Oil.

\section{INTRODUCTION}

Indonesia is the second largest producer of palm oil in the world after the Philippines and has managed to produce about 2.8 tonnes of palm oil and exports by 273,000 tonnes. As much as $49 \%$ of the total demand for palm oil is used for the domestic benefit of cooking oil and the rest for the industry, thus the greater demand for cooking oil production then the used cooking oil is also increasing [1]

The use of cooking oil for the household sector is quite large, which is about 6 liters in a month. The price range for cooking oil in the market is widely used in households currently Rp. 13,000 per liter [1]. More and more consumption of cooking oil is more and more common oil is used in the monthly household sector.

The use of repeated cooking oil or more often used, the higher the oil damage level. The damage that includes the increase of free fatty acids, the emergence of oil viscosity, the formation of foam and the presence of impurities from the seasoning used and ingredients are fried. The use of oil many times will result in oil getting dirty and brown to black and the disliked flavor of the food ingredients are fried [2].

A free fatty acid or Free Fatty Acid (FFA) is a fatty acid that has been detached from the glycerol molecule, or saturated fatty acids formed due to the hydrolysis of the oil. The number of free fatty acids in oil indicates the decline in the oil quality [3].

The use of cooking oil used more than once for frying is a common thing among the people. Some people think foods that are mixed with used cooking will be more delicious, but the result of degradation reaction to the oil used repeatedly will decrease the quality of food ingredients that are fried and cause negative effects [4]. 
The quality requirement of palm cooking oil for free fatty acids according to $\mathrm{SNI}$ is maximum $0.3 \%$ [5], which when consumed more than the standard will damage health, this is due to the viscosity to be dense so that it is sticky on blood duct walls that result in atherosclerosis, causing increased weight of kidney and liver organs as well as the onset of various diseases, such as hypertension, coronary heart disease, and cancer [6].

Seeing the abundance of oil from household and industrial waste in high quantities and aware of the danger of consuming oil used cooking then it is necessary to do innovation to utilize the common oil so as not to pollute the environment, in addition it can be used again as raw materials and supporting materials on industrial activities such as for the manufacture of soap and biodiesel fuel [7], and one of the methods to improve the quality of the used cooking oil is adsorption. Various efforts have been made to regenerate the oil, namely by reducing the content of free fatty acids through adsorption method [8]. Among them are using adsorbent avocado seeds that can lower the oil-free fatty acid levels of used cooking from $0.46 \%$ to $0.26 \%$ [9].

Other research uses oil palm empty fruit charcoal that can reduce the levels of free fatty acids in oil used cooking from $2.63 \%$ to $0.1315 \%$ [5], but also research using sugarcane as adsorbent oil that can Reduce the free fatty acids from $0.3 \%$ to $0.15 \%[10]$.

This research, researchers will use active carbon Alang-alang as adsorbent to lower free fatty acids and color in oil, due to the presence of silica and high cellulose biopolymer that naturally gives the structure Porous so that the material can be used as Adsorption media [11].

Based on the background, the author is interested to examine the decline in the free fatty acids and the color of oil in common use carbon active of reeds (Imperata cylindrica L. Raeusch) with variations of the adsorbent concentration used as an absorbent medium.

\section{RESEARCH METHODS}

\section{Tools and Materials}

Tools used, furnaces, oven, mouthpiece, stirrer, hot plate, magnetic stirer, $\mathrm{pH}$ meter, aluminium foil, sieve size 100 mesh, separating funnel, pipette drops, pipit volume, Burette, statif, Beaker glass, erlenmeyer, glass watch, pumpkin measure, measuring cup, mortar and Stamper, analytical scales, filter paper, scissors, UV-Vis spectrophotometry.

The materials used, cooking oil fried and used cooking oil pecel lele, Alang-Alang (Imperata cylindrica L. Raeusch), Aquadest $\left(\mathrm{H}_{2} \mathrm{O}\right)$, sodium hydroxide $15 \%(\mathrm{NaOH})$, potassium hydroxide $0,1 \mathrm{n}(\mathrm{KOH})$, indicator Fenolftalein (PP), ethanol $96 \%\left(\mathrm{C}_{2} \mathrm{H}_{5} \mathrm{OH}\right)$, Sodium chloride $30 \%(\mathrm{NaCl})$, and oxalic acid $\left(\mathrm{H}_{2} \mathrm{C}_{2} \mathrm{O}_{4} \cdot 2 \mathrm{H}_{2} \mathrm{O}\right)$.

\section{Methods}

\section{Plant Determination}

The reeds will be used for first research in determination. Determination is done in the Botany Laboratory of Biology department FMIPA Lampung University.

\section{Preparation of Carbon Active}

\section{a. Sample preparation}

The reeds was prepared for $\pm 2 \mathrm{~kg}$, then washed using clean water and flowing to remove the dirt attached to the reed. After that the reeds are dried under the sun until dry, after the dried reeds are cut into small sizes.

\section{b. Chemical activation}

The reed is activated by soaking it in a solution of $\mathrm{NaCl} 30 \%$ [1]. The reeds was soaked for 24 hours, after it was filtered and dried in the oven at a temperature of 1000 C for 2 hours [12]. 


\section{c. Carbonization}

The activated Reed is further carbonized in the $300 \circ \mathrm{C}$ Temperature Furnace for 2 hours. The formed charcoal is pounded with a mortar and then sifted using a sieve size of 100 mesh [12].

\section{d. Washing}

The sifted activated carbon is washed with a $1 \mathrm{M} \mathrm{HCl}$ solution, followed by leaching using heat aquades to a neutral $\mathrm{pH}$, after washing activated carbon is drained at a temperature of $100 \circ \mathrm{C}$ for 2 hours. So derived the synthesis of the homogenous carbon active of reeds [12].

\section{Purification process}

\section{a. Despicing process}

The oil is inserted in a gorengan and pecel lele each into a beaker glass $1000 \mathrm{~mL}$, then each oil is mixed with water with the composition of oil and water (1:1), while heated above the Hot plate temperature $1100 \mathrm{C}$ to water in a beaker glass lived half. The oil and water coating is separated using a separator funnel, the oil is accommodated to the next process [13].

\section{b. Neutralization Process}

Prepared a $\mathrm{NaOH} 15 \%$ solution that has been created, then used cooking oil of gorengan and pecel Lele despicing results are each heated above the hot plate at a temperature of $\pm 40 \circ \mathrm{C}$, then inserted a solution $\mathrm{NaOH} 15 \%$, with the composition (oil: $\mathrm{NaOH})=(100 \mathrm{ML}$ of oil: $5 \mathrm{ml} \mathrm{NaOH})$. Then the mixture is stirred for 10 minutes using a magnetic stirer with a speed of 500 rpm, after which the oil of neutralization results is filtered with a filter paper [13].

\section{c. Bleaching Process}

Prepared as much as 10 cups beaker 250 $\mathrm{ml}, 5$ pieces of beaker filled each $100 \mathrm{ml}$ of cooking oil fried and 5 pieces of beaker filled each $100 \mathrm{ml}$ of oil used cooking Pecel lele, subsequent oil heated above the temperature hotplate $70{ }^{\circ} \mathrm{C}$, and Inserted activated carbon Alang-alang as much as $2.5 \mathrm{~g}$ (concentration 2.5\%); $5 \mathrm{~g}$ (concentration 5\%); $7.5 \mathrm{~g}$ (concentration 7.5\%); $10 \mathrm{~g}$ (concentration 10\%); and 12.5 $\mathrm{g}$ (concentration 12.5\%) into each beaker that has contained $100 \mathrm{~mL}$ of oil fried and used cooking pecel Lele, while stirring using a magnetic stirrer for 30 minutes with a speed of $500 \mathrm{rpm}$, then filtered and used cooking oil results purification is prepared to be tested for free fatty acid levels using the base acid titration method and the color change test with UV-Vis spectrophotometry.

\section{Test parameters}

\section{a. Analysis of free fatty acid levels}

Weighed 1 gram of purification oil samples using the carbon active reeds into Erlenmeyer $250 \mathrm{~mL}$, and added $25 \mathrm{ml}$ ethanol $96 \%$. Then the Erlenmeyer is heated over the hot plate temperature of 80 ${ }^{\circ} \mathrm{C}$, and after that it is added as many as 3 drops of the phenolphthalein (PP) indicator and then do the titration using a 0.1 solution of not disappear for 30 seconds. Free fatty acids are expressed with a percent of free fatty acids, which are calculated using the following equations:

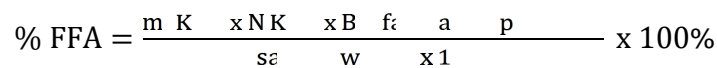

Description:

FFA = Free Fatty Acid levels

$\mathrm{mL} \mathrm{KOH}=\mathrm{KOH}$ titrant volume

$\mathrm{N} \mathrm{KOH}=$ Solution normality of $\mathrm{KOH}$ (mol/L)

$\mathrm{BM}=$ Molecular weight of fatty acids (fatty acids palmitate) $256 \mathrm{~g} / \mathrm{mol}$

\section{b. Analysis of discoloration (Absorbance)}

The oil color is measured using UV-Vis spectrophotometry. The oil samples were inserted into the cuvettes, after which the absorption was measured at $460 \mathrm{~nm}$ wavelengths using the initial oil samples as Blanko.

\section{Data Analysis Methods}

Data will be analyzed using a test of homogenity to know the variance of data 
homogeneous or not, the test of Anova One-Way to know whether there is an influence of the addition of the concentration of active carbon reeds to decrease in free fatty acid levels and advanced test Duncan to see the comparison of the average pair of carbon active concentrations of reeds signifi-cantly different. This data analysis uses SPSS 24 software.

\section{RESULTS AND DISCUSSION}

Effect of carbon active concentrations on free fatty acid levels

One of the determining parameters of cooking oil quality is the free fatty acid levels formed due to the hydrolysis process of oil, which can cause oil damage due to the presence of some water in oil that is accelerated by Heat factors, acidity and enzymes. The more often the oil is used, the greater the free fatty acid levels are formed [14].

The free fatty acids in palm oil are defined using the base acid titration method using a secondary raw that is $\mathrm{KOH}$. The function of adding ethanol $96 \%$ in the sample before the administration is to dissolve the oil in order to easily react with the alkaline base. The function of heating (reflux) at the time of the experiment is to allow the oil to dissolve completely in ethanol and rapid reaction [15]. Here is a table of results of free fatty acids at used cooking oil.

Table 1. Results determination of free fatty acid levels

\begin{tabular}{c|c|c|c|c}
\hline \multicolumn{5}{c}{ Used cooking oil of gorengan } \\
\hline & $\begin{array}{c}\text { Konsentration } \\
\text { of carbon } \\
\text { active (\%) }\end{array}$ & Free fatty acids (\%) & \multirow{2}{*}{ Decrease } \\
\cline { 2 - 4 } No. & \multicolumn{1}{c}{ Before } & After & $(\%)$ \\
\hline 1. & 2.5 & 1.792 & 0.896 & 50 \\
\hline 2. & 5 & 1.792 & 0.597 & 66.68 \\
\hline 3. & 7.5 & 1.792 & 0.384 & 78.57 \\
\hline 4. & 10 & 1.792 & 0.426 & 76.22 \\
\hline 5. & 12.5 & 1.792 & 0.469 & 73.82 \\
\hline \multicolumn{5}{|l|}{ Used cooking oil of pecel lele } \\
\hline 1. & 2.5 & 2.218 & 1.109 & 50 \\
\hline 2. & 5 & 2.218 & 0.682 & 69.25 \\
\hline 3. & 7.5 & 2.218 & 0.469 & 78.85 \\
\hline
\end{tabular}

\begin{tabular}{l|l|l|l|l}
4. & 10 & 2.218 & 0.512 & 76.91 \\
\hline 5 & 12.5 & 2.218 & 0.597 & 73.08 \\
\hline
\end{tabular}

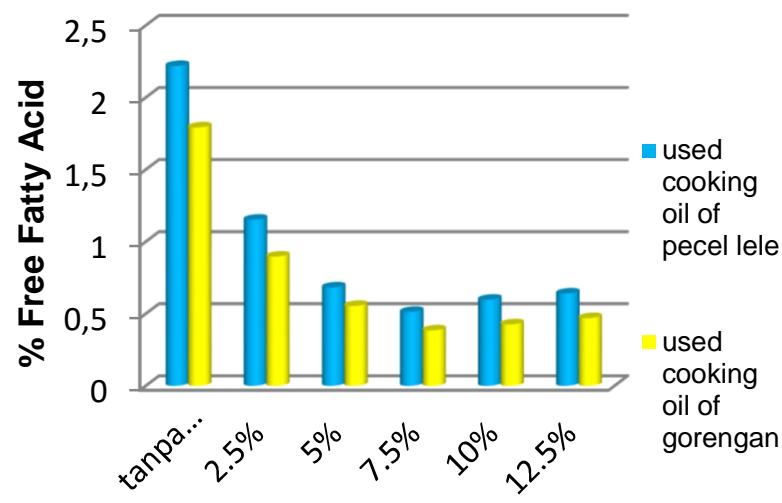

Konsentration of carbon active

Figure 1. A Diagram of the influence of activated carbon contacts on the levels of free fatty acids.

Based on the data in the tables and diagrams above, the results obtained showed that the free fatty acid levels of the used cooking oil of gorengan and pecel Lele (without adsorbent) respective-ly at $1.792 \%$ and $2.218 \%$. The high levels of free fatty acids in the barley oil can be caused by high levels of oil damage due to the process of oxidation and hydrolysis [16]. The heating process at high temperatures and oil contact with air can accelerate the oxidation process. Meanwhile, the process of hydrolysis occurs due to the presence of water in oil with repeated heating at high temperatures can lead to the formation of free fatty acids in oil [17]. The reduction of free fatty acids occurs due to the addition of the carbon active of reeds that can absorb free fatty acid molecules. The adsorption process of activated carbon occurs through the three basic phases, i.e. the substance absorbed in the outside, then moving towards the pores of the carbon and absorbed into the inner wall of the carbon. Carbon active of reeds can be seen in Figure 2 below : 


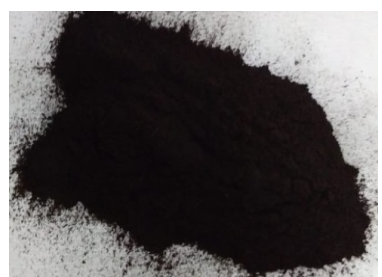

Figure 2. Carbon Active of Reeds

Based on the data presented, the level of fatty acids oil-free barley pecel Lele is higher than the used cooking oil of gorengan. In the concentration of adsorbent $2.5 \%-7.5 \%$ occurs increased ability of free fatty acids adsorption by carbon active of reeds, but at the concentration of adsorbent 10\%-12.5\% The absorption is relatively decreased, this is due to the occurrence of desorption process is relinquishment of ions or molecules that have been bonded to active groups on adsorbents. On the surface of adsorbent is an active site that is comparable to the surface area of the adsorbent, so that when the site is active on the wall surface adsorbent cells have achieved maximum adsorb ability, the addition of active carbon concentrations is can not improve the adsorption ability of the adsorbent [18]. The adsorption and desorption process of adsorbent can be seen in Figure 3 below:

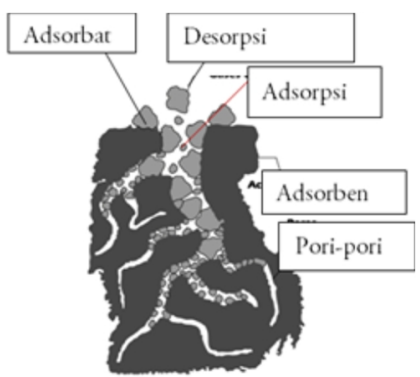

Figure 3. adsorption process and desorption into adsorbent pores [19].

After the data obtained percentage of oil free fatty acid decline, then conducted statistical data analysis using One Way Anova test. The requirement in One Way Annova test is that the data obtained must be homogeneous. Therefore it is done in advance a test of homogeneity to the data obtained.
Based on the test of homogeneity of the data obtained has the same variant in the used cooking oil of gorengan is the value of sig. $0.302>0.05$ and in Pecel Lele has a value of sig. $0.464>0.05$ So it proves that the data obtained homogeneous. The results of One Way Anova test obtained the value of sig. $0.000<0.05$ so that the results are significantly achieved. This proves that there is an influence on the addition of active carbon reeds to decrease in oil-free fatty acid levels. Further analysis results using the DMRT test at a 5\% level indicating the free fatty acid negative control (without adsorbent) is distinct from the concentration of $2.5 ; 57.5 ; 10$ and $12.5 \%$ which means it has an effect in lowering the free fatty acid levels in common oil. The concentration of $7.5 \%$ does not differ with the concentration of $10 \%$ and $12.5 \%$ meaning the concentration of $7.5 \%$ has the same effect as the concentration of $10 \%$ and $12.5 \%$ in lowering the oil-free fatty acid levels of used cooking oil, at concentrations of $5 \%$, $10 \%$, and $12.5 \%$ also has similarities in lowering the oil-free fatty acid levels of used cooking oil, and the concentration of $2.5 \%$ have a noticeable difference with all concentrations. Although free fatty acids are increased back at a concentration of $10 \%$ and $12.5 \%$ but it does not differ real with a concentration of $7.5 \%$. The optimum adsorption of the study is $7.5 \%$ concentration because it can reduce the highest levels of free fatty acids, namely reaching a decrease in the amount used cooking oil of gorengan and pecel lele respectively at $78.57 \%$ and $78.85 \%$.

\section{Effect of adding adsorbents to color concentrations (absorbance)}

The use of oil many times will increase the color change to brown until blackish due to the impurities of the frying ingredients and mix the substances from the ingredients that are fried into the oil [20]. Oil color is caused by the presence of pigments, from palm oil itself and the pigment of the cooking spices [21] dark color, caused by oxidiated oil components such as carotenoids and vitamins during the frying 
process, also because of the color of the ingredients that are cooked dissolved in oil.

Fats and oils contain za-dyestuffs that can absorb light spectrum, the level of impurities can be seen by looking at the absorption of the material being charged, the higher the absorbance then the concentration of the impurities are getting higher [21]. Absorption of oil against the apparatus due to the presence of hydroxyl groups and other clusters that can absorb long wavy infrared rays. A double bond between the carbon and carbon will absorb the short wavy ultraviolet rays, which can therefore be measured by a spectrophotometer [21] A clear measurement of the color clarity of oil that has been given treatment with activated carbon of reeds, measured using UV-Vis spectrophotometry tools. The clarity of the oil is measured at a wavelength of $460 \mathrm{~nm}$ [1] and the Absorbancy states the degree of turbidity. Used cooking of gorengan has a value of absorbance 1.795 and barley oil pecel Lele has absorbance amounting to 2.521. The greater the absorption at this wavelength indicates the darker color of the oil. This means more and more oil degradation products [22]. The following is the result of measurement of absorbance in used cooking of gorengan and pecel lele.

Table 2. Result of measurement the absorption of used cooking oil of gorengan and used cooking oil of pecel Lele

\begin{tabular}{l|l|c|c}
\hline \multirow{2}{*}{} & \multirow{2}{*}{$\begin{array}{c}\text { Persentage } \\
\text { Carbon } \\
\text { Notive (\%) }\end{array}$} & $\begin{array}{c}\text { Average of } \\
\text { absorbance }\end{array}$ \\
\cline { 3 - 4 } & $\begin{array}{c}\text { used } \\
\text { cooking } \\
\text { oil of } \\
\text { gorengan }\end{array}$ & $\begin{array}{c}\text { used } \\
\text { cooking } \\
\text { oil of } \\
\text { pecel lele }\end{array}$ \\
\hline 1. & Kontrol & 1.795 & 2.521 \\
\hline 2. & 2.5 & 0.574 & 0.691 \\
\hline 3. & 5 & 0.435 & 0.609 \\
\hline 4. & 7.5 & 0.347 & 0.515 \\
\hline 5. & 10 & 0.407 & 0.563 \\
\hline 6. & 12.5 & 0.410 & 0.582 \\
\hline
\end{tabular}

Description: The result is an average of 3 times repeated.

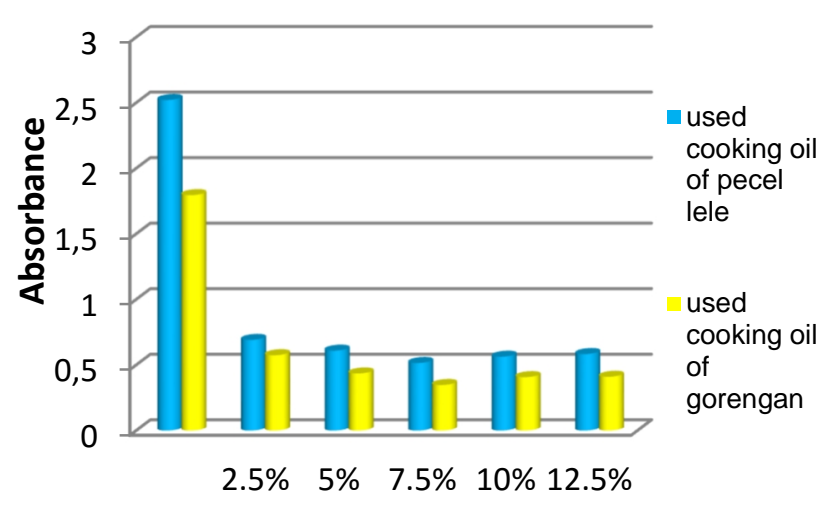

Konsentration of Carbon Active

Figure 4. The influence of activated carbon conduits impact diagram on absorbancy value.

In both samples the oil showed that the concentration of $7.5 \%$ had the least absorbance compared to other concentrations. Addition carbon active of reeds with a variety of concentrations of 2.5; $57.5 ; 10$ And $12.5 \%$ indicate the same color change to be golden yellow and clear. The process of absorption of dyestuffs by activated carbon is similar to the process of absorption of free fatty acids. Active carbon absorbs colour and dirt contained in the common oil produced from the seasoning of deep-fried ingredients. Activated carbon can absorb dyestuffs and can also absorb some of the unwanted odor found in the common oil [21].

The result of absorbance value obtained by reading using Insrumen spectrophotometry is the oil that has been purified with the addition of activated carbon as much as $7.5 \%$ has the least absorption value compared to the other concentration. The results of the homogenity test showed that the cooking oil has a sig value of $0.00<$ 0.05 , and the barley of pecel lele has a sig value of $0.00<0.05$ so that the data obtained is heterogeneous. Based on the coefficient of uniformity value obtained for the used cooking oil of gorengan is $0.1333 \%$ and the used cooking oil of pecel lele is $0.9164 \%$ which means the value of the coefficient of uniformity obtained small or $\mathrm{KK} \leq 10 \%$, then continued using the Advanced Test Tukey. The results of the advanced Tukey test indicate that the 
absorption of negative control absorbance (without adsorbent) is distinct from the concentration of $2.5 ; 57.5 ; 10$ and $12.5 \%$. Concentrations of $2.5 \%$ differ in real with all concentrations, as well as 5 concentrations; 7.5 ; $1012.5 \%$ is also completely different with all concentrations, so it can be concluded that adsorption with activated carbon from the reeds that gives the lowest absorption value is at the concentration of activated carbon $7.5 \%$, which can decrease the absorption of used cooking oil of gorengan from 1.795 to 0.347 and lowered the absorbance in pecel lele oil from 2.521 to 0.515 .

\section{CONCLUSIONS AND SUGGESTIONS}

\section{Conclusion}

Carbon active of reeds can be used as an adsorbent in the process of refining oil. The results showed the most optimum concentration of activated carbon to lower the level of free fatty acids and the color in the used cooking oil at a concentration of $7.5 \%$.

\section{Suggestion}

Based on the results of the research that has been done, then the next study is advised to conduct research using activated carbon reeds from different oil sources.

\section{ACKNOWLEDGMENTS}

Thank you to Tulang Bawang Lampung University Laboratory staff, Laboratory SMK SMTI Bandar Lampung, and Lampung Province Health Laboratory.

\section{REFERENCES}

[1] Aziz T, Shabrina D, Pratiwi RN. Penurunan Kadar FFA dan Warna Minyak Jelantah Menggunakan Adsorben dari Biji Kurma dan Kulit Salak. Jurnal Teknik Kimia. 2016;22(1):43-8.

[2] Lempang IR, Fatimawali NCP. Uji Kualitas Minyak Goreng Curah dan
Minyak Goreng Kemasan di Manado. Jurnal IImu Farmasi. 2016;5(4).

[3] Barau F, Nuryanti S, Pursitasari D. Buah Mengkudu (Morinda Citrifolia L.) Sebagai Pengadsorbsi Minyak Jelantah. Jurnal Akademi Kimia. 2015; 4(1):8-16.

[4] Sopianti DS, Saputra HT, Bengkulu AFA. Penetapan Kadar Asam Lemak Bebas Pada Minyak Goreng. Jurnal Katalisator. 2017; 2(21):100-5.

[5] BSN. Badan Standarisasi Nasional Indonesia. 2012. SNI No 7709 : 2012. Minyak Goreng Sawit. Badan Standarisasi Nasional. Jakarta.

[6] Alfiani S, Liling TMN. Analisis Kadar Asam Lemak Bebas dalam Minyak Hasil Penggorengan Berulang dengan Metode Titrasi Asam Basa dan Spektrofotometer Fourier Transformation Infra Red (FTIR). Jurnal Pharmascience. 2014;1(1):7-13.

[7] Mardiah, Dkk. Proses Pemurnian Minyak Jelantah Menggunakan Ampas Tebu untuk Pembuatan Sabun Padat. Jurnal Integrasi Proses. 2016;6(2):57-63.

[8] Juliana IN, Tandi S, Said I. Pemanfaatan Buah Mengkudu (Morinda Citrifolia L.) Sebagai Adsorben untuk Meningkatkan Mutu Minyak Jelantah. Jurnal Akademika Kimia. 2015;4(4):1818.

[9] Fitriani, Nurulhuda. Pemurnian Minyak Goreng Bekas Menggunakan Adsorben Biji Alpukat Teraktivasi. Jurnal Pendidikan Matematika dan IPA. 2018; 9(2): 65-75. 
[10] Hajar, EWI. Mufidah, Siril. Penurunan Asam Lemak Bebas pada Minyak Goreng Bekas Menggunakan Ampas Tebu untuk Pembuatan Sabun. Jurnal Integrasi Proses. 2016;6(1):22-27.

[11] Hidayat SRA. Utilization Of AlangAlang (Imperata Cylindrica (L.) Raeusch.) As Traditional Medicine In Indonesian Archipelago. Jurnal Proceedia. 2017;

[12] Khilya A. Prasetya AT. Optimasi dan Aplikasi Arang Aktif Alangalang untuk Menurunkan Kadar Cd(II) dalam Larutan. Indonesian Journal Of Chemical Science. 2016;5(1):6-10.

[13] Yustinah. Pengaruh Tempatur Pada Proses Pemurnian Minyak Goreng Bekas dengan Buah Mengkudu. Jurnal Konversi. 2015;4(2):53-62.

[14] Almatsier S. 2009. Prinsip Dasar IImu Gizi. Jakarta: PT. Gramedia Pustaka Utama; 50-74 P.

[15] Suroso, AS. Kualitas Minyak Goreng Habis Pakai Ditinjau dari Bilangan Peroksida, Bilangan Asam dan Kadar Air. Jurnal Kefarasian Indonesia. 2013;3(2):77-88.

[16] Nurbasnawati, H. Penetapan Kadar Asam Lemak Bebas dan Bilangan Peroksida Pada Minyak Goreng yang digunakan Pedagang Gorengan di Jalan A.W Sjahranie Samarinda. Jurnal IImiah Manuntung. 2015;1(1).

[17] Nasir, NSW., Nurhaeni \& Musafira. Pemanfaatan Arang Aktif Kulit Pisang Kepok (Musa Normalis) Sebagai Adsorben untuk Menurunkan Angka Peroksida dan Asam Lemak Bebas Minyak
Goreng Bekas. Online Jurnal Of Natural Science. 2014;3(1).

[18] Sembiring, MT., Sinaga, TS. 2003. Arang Aktif (Pengenalan dan Proses Pembuatannya). Skripsi. Jurusan Teknik Industri Fakultas Teknik Industri Fakultas Teknik USU. Medan.

[19] Lestari, S. Pengaruh Berat dan Waktu Kontak untuk Adsorpsi Timbal(II) oleh Adsorben Kulit Batang Jambu Biji (Psidium Guajava L.). Jurnal Kimia Mulawarman, 2010;8(1):6-9.

[20] Winarno, F.G, 1992, Kimia Pangan dan Gizi, PT. Gramedia Pustaka Utama, Jakarta.

[21] Ketaren, S. 1986. Pengantar Teknologi dan Lemak Pangan. Jakarta :UI Press;

[22] Said, I. Gonggo, ST. Juliana NI. Pemanfaatan Buah Mengkudu (Morinda Citrifolia L.) Sebagai Adsorben untuk Meningkatkan Mutu Minyak Jelantah. J. Akad. Kim. 2015;4(4):181-188. 